\title{
Doctoral Supervisors and PhD Students' Perceptions about the Supervision Process in a Young European University
}

\author{
Isabel Ribau \\ School of Science and Technology, Universidade NOVA de Lisboa (NOVA), Portugal \\ Received September 5, 2019; Revised November 22, 2019; Accepted December 17, 2019
}

Copyright $\mathrm{O} 2020$ by authors, all rights reserved. Authors agree that this article remains permanently open access under the terms of the Creative Commons Attribution License 4.0 International License

\begin{abstract}
In the last decade with the Bologna implementation, doctoral supervision gained a new emphasis and emerged as crucial for developing the European research area. Research, on doctoral supervision practices, and the supervisor ideal profile was carried out in a TOP 10 young European university, at Universidade Nova de Lisboa. The results show that meetings (individual or in groups) are the most implemented practice. Usually, students present orally, to a supervisor, the research that they already made regarding the initial work plane. Two supervisors' profiles emerge from the students' voices, the real and the ideal. The ideal supervisor profile that emerges from the questionnaires features supervisors who take students care, give feedback on work on time, and are honest and critical.
\end{abstract}

Keywords PhD Students, PhD Supervisor Profile, Supervision, Practices, Monitorization, Evaluation

\section{Introduction}

The changing in the profile of the doctorate in the last decade and the expectation of employability outside the academy brought new aims for doctoral education and new challenges to the supervision process (Halse \& Malfroy, 2010; Lee, 2018; Fillery-Travis, Maguire, Pizzolatti, Robinson, Lowley, Stel \& Mans, 2017; Denis, Colet \& Lison, 2019). This alteration started in the Lisbon strategy in 2000, with the definition of EHEA (European Higher education Area) and ERA (European research area) and in Europe it has been imposing since then (Repečkaitè, 2016).

\subsection{PhD Research Supervision Practices}

Look to doctoral supervision, through doctoral students' lenses and supervisors' point of view is important to perceive the health of doctoral education and underline the importance of it. Identify doctoral experience - what $\mathrm{PhD}$ students do (did) during their doctorate (tasks, practices, participation in seminary and meetings, participation in the institution's activities) and their difficulties- may help to increase the productivity, students' wellbeing and reduce time-to-complete the degree. On the other hand, perceive the supervisor research supervision methodology and what tasks are proposed to $\mathrm{PhD}$ students may contribute to identify good practices and reduce the unproductive or unsuccessful ones which may help to improve the supervision process.

The doctorate as Green said in 2005, "as much about identity formation as it is about knowledge production" (Green, 2005). It is based on a relationship between the supervisor and the doctoral student and implies flexibility, negation, power issues, subjectivity, being a fluid task (Connell, 1985; Love \& Street, 1998; Grant 1999)

Some supervisory practices that may reduce $\mathrm{PhD}$ student attrition and drop out are, writing and acceptance by doctoral students and supervisor of rights and obligations (written contract/rules defined by both) (Latona \& Browne, 2001; Halse \& Malfroy, 2010) and the training of skills/competence of induction and/or research using proper research environment (Fraser \& Mathews, 1999; Latona \& Browne, 2001). The development of students' ability to balance creativity and criticism (Kobayashi, Grout \& Rump, 2015; Fenge, 2012), the regular seminars on the progress of research and cohort meetings (Burnett, 1999), but also participation in conferences and workshops or participate in formalized peer meetings. The supervision by academic panels, informal meetings, and collaborative meetings may also promote the research skills development (Latona \& Browne, 2001; Pearson, 1996; Pearson, 2012) as the supervisor timely feedback throughout the $\mathrm{PhD}$ (Denis, Colet \& Lison, 2019; Corcelles, 
Cano, Liesa \& González-Ocampo, 2019). But learning environments should also include writing research reports (to monitor progress) and or co-writing (supervisor and doctorate), but also peer writing group support (Dorn, Papalewis \& Brown, 1995; Wegener \& Tanggaard, 2013; Aitchison \& Guerin, 2014; Lindsay, 2015). The use of postgraduate registration books - logs or logbooks (Conrad, Perry \& Zuber-Skerritt, 1992; Yeatman, 1995) or research books (research diary) can also help. The student financial support increase (Latona \& Browne, 2001; Wollast, Boudrenghien, Linden, Galand, Roland, Devos, De Clercq, Klein, Azzi \& Frenay, 2018) and the socialization of the $\mathrm{PhD}$ student in the research group, which includes a good institutional climate, the promotion of a sense of belonging, the inclusion of students in departmental activities, a physical space (office) and technical support (Pearson, 1996; Gardner, 2008 and 2010) are also good practice to promote the completion of the degree. But is also important that institutions have a clear research studies policies (codes of practices; code of conduct; quality assurance in research degrees; research degrees regulations; ethical principles; guidelines) (Latona \& Browne, 2001; Abiddin \& West, 2007) and implement the role of a counsellor-trained mentor (Pearson, 2012) and peer support.

It is important to mention that the sense of belonging may be linked to the pedagogical continuity that occurs when a doctorate is integrated into a research group, if it is understood as "inter-generational transmission of knowledge and skills, and to the reproduction of academic habits in its different guises" (Delamont, Parry \& Atkinson, 1997). The research group provides networks of social relationships that can support the doctoral student. That way the doctoral student enrols in the habits of his disciplinary area, which includes "embodied craft skills and a commitment of trust in his experiments" and also shares academic capital (equipment, problems, and knowledge). It is important to emphasize that social/academic isolation may pro-mote doctorate retention and attrition (Ali \& Kohun, 2007; Gardner, 2008).

Another proposal to help doctoral students is the use of learning plans that can be applied online; allow both the student and the supervisors to monitor the work being developed (Ayers, Kiley, Jones, McDermott \& Hawkins, 2016). Student support (mentoring) by peers is another proposed strategy that has proven to be able to help doctoral students overcome the difficulties encountered during their $\mathrm{PhD}$. This strategy benefited both the mentors and the students who received the support and allowed a better integration of the latter (Mason \& Hick-man, 2017).

Vekkaila, Pyhältö, Hakkarainen, Keskinen, and Lonka, in their study in 2012, with PhD Students, underlined the personal significance of participation in academia, and their development as scholars and researchers, who develop research skills specific to natural sciences but also learn to manage institutional tasks and doctoral research.
They place key learning experiences in collaborative academic contexts, identifying them with research activities, training courses, and peer-to-peer meetings and with other researchers.

\subsection{The PhD Student Profile and Practices, Challenges and Difficulties}

Nowadays the doctorate is taken by adult students, novice or mature students. This diversity of the student population implies specific pedagogies and different approach by the supervisor (Lee, 2008; Johnston, Sampson, Comer \& Brogt, 2016; Fillery-Travis \& Robinson, 2018). In this context, when we look to the novice or mature students, the roles of doctoral supervision should be different. As Maxwell and Smyth $(2010,2011)$ refer, the power relation may not be as straight as in the traditional $\mathrm{PhD}$ or the other degrees (Bachelor or master), especially if we are talking about the professional doctorate. The supervision approach must be different and as Fillery-Travis and Robinson (2018) say "there is a significant change in the purpose of a doctorate from the training of an academic to the higher-level development of advance practitioners" and with it arises the changes in the doctoral pedagogy and practices. To recognize what is the aim for the doctorate from the supervisor point of view, can give some clues to the proposed practices (Bruce \& Stoodly, 2013; Loxley \& Kearns, 2018) or as we did in this work, look to the tasks proposed by supervisor we can understand what is the meaning for the doctorate from the supervisor point of view. In this sense, it is important to identify the supervisors' role and practice that a $\mathrm{PhD}$ student experience during the doctorate in UNL.

Carter, Kensington-Miller and Courtney (2017) in recent research in New Zealand, namely at University of Auckland, identified a new approach for the $\mathrm{PhD}$, as they refer "there are emerging new options for doctorate processes" practice-based, with performance and by publication. But these changes occurred in many countries like Portugal, where is possible to complete the $\mathrm{PhD}$ by publications. And the challenging is the doctoral pedagogy adjustments and changes it implies. Some strategies used in this context are, general support for student learning, by research groups or departments, peer writing group support (Carter \& Laurs, 2014; Aitchison \& Guerin, 2014) but also short courses proposed by Doctoral Schools as in UNL. In the case of UNL Doctoral School, the course diversity, presented to students, intending to reinforce or develop not only doctoral students' transferable skills but also transversal skills. PhD students of all areas (economics, natural science, law, social science, health science) and from other Universities can be enrolled. This support is a strategy to improve the completion rate, but also to diminish the attrition rate without being intrusive to the supervision process.

At Canterbury University they applied a survey 
(University of Canterbury postgraduate experience survey - UCPEQ) to assess the on-going experiences of the research students. The survey assesses information related to the provision of supportive environment research, the importance of the students-supervisor relationship, but also the students' ability to achieve their goals and aspirations, and helps to define the supervision practices. As the authors refer "The UCPED serves as a formative tool, based within an academic development agenda, providing detailed information that can, and has, changed supervision practices and the research experiences for students" (Johnston, Sampson, Comer \& Brogt, 2016).

But a new movement that is growing after the Bologna implementation is also the supervisor support that is begin given by the higher institutions, as is reported by Kiley (2011). In UNL Doctoral School is following this international movement, and since 2013 is offering also $\mathrm{PhD}$ supervisors a short course related to supervision. It intends to reinforce the supervisors' professional development and create supervisors supporting networks.

Although all these strategies are important, the supervisors' role still is the key to the $\mathrm{PhD}$ completion, being important to recognize the supervisor profile that is emerging now, and what doctoral supervision practice is to propose to doctoral students.

\section{Methodology}

Two surveys to identify the supervision practices, monitorization and evaluation were constructed. The surveys were delivered, via institutional e-mail, to all nine schools that belong to Universidade Nova de Lisboa (Faculdade de Ciências e Tecnologia (FCT); Faculdade de Ciências Sociais e Humanas (FCSH); A NOVA School of Business and Economics (NSBE); NOVA Medical School / Faculdade de Ciências Médicas (NMS/FCM); Faculdade de Direito (FD); Instituto de Higiene e Medicina Tropical (IHMT); NOVA Information Management School (NIMS); Instituto de Tecnologia Química e Biológica António Xavier (ITQB); Escola Nacional de Saúde Publica (ENSP)), and they were sent to the PhD supervisors and students. The surveys were open for three months. $112 \mathrm{PhD}$ supervisors answered the survey and $250 \mathrm{PhD}$ students also responded to the student survey.

To answer the survey close questions, doctoral students had to agree, partially agreed, partially disagree or disagree with positive and negative sentences. They also had an inventory of supervision practices and characteristics of a good supervisor and one optional open-ended questions related to the reason to be enrolled in a $\mathrm{PhD}$ and two inventories.

To respond the questionnaire close questions, doctoral supervisors had to agree, partially agreed, partially disagree or disagree with positive and negative statements. They had in the survey an inventory of supervisory practices and two optional open-ended questions related to the reason to be a $\mathrm{PhD}$ supervisor and the personal meaning of take a $\mathrm{PhD}$.

The scale's internal reliability, Cronbach's alpha was 0.901 , to the students' survey and 0.946 to the Supervisors survey.

\section{Results and Discussion}

We now present some results regarding the supervisor role and practice from the students' and supervisor point of view. We also present the results related to the ideal supervisor from the students' lens.

\subsection{Characterization of the Respondent Population}

\subsubsection{PhD Student's Profile}

The PhD students were from UNL. Four per cent have less than 25 years old, forty-five per cent have between 25 and 30 years old, twenty-one per cent twenty one have between 31 and 35 years old and thirty per cent have more than 35 years old. So we have a novice, but also mature students.

Twenty-eight per cent of the PhD students are enrolled in part-time, and $72 \%$ are enrolled in full-time.

Twenty-six per cent of the PhD students were in the first year of $\mathrm{PhD}$ frequency, sixteen per-cent was in the second year, twenty-three per cent in the third year, eighteen per cent in the fourth year and seventeen were enrolled over four years ago.

\subsubsection{PhD Supervisor Profile}

From the 112 supervisors that answer the survey, it is possible to verify that 100 supervisors come from Science, Technology, Engineering and Health Sciences area (CTES) (FCT, IHMT, ITQB and ENSP) and 12 from the Economics and Management and Social and Human Sciences area (ECSH) (Nova SBE, FD, FCSH, Nova IMS). The data related to age and gender were not collected.

Twenty-four point one per cent (24.1\%) of $\mathrm{PhD}$ supervisors has been in this activity for 1 to 5 years, $27.6 \%$ from 6 to 10 years and $48.3 \%$ for over 11 years. The number of mentored or co-supervised PhD students was also collected, with the majority of the supervisors (56.3\%) having between one and two students as the majority of the co-supervisors $(64.3 \%)$. However, it should be noted the supervisors who indicate having 5 or more orientations $(15.2 \%)$ and co-supervisors (3.6\%). The quality descriptors for doctoral supervision of the Association of European Biomedicine and Health Sciences institutions and colleges (ORPHEUS, 2011 and 2012) advise the existence of a principal supervisor and a co-supervisor to cover the various aspects of a project, but also that the number of students per supervisor should be commensurate with the work of each supervisor. 
Concerning the attendance of the doctoral school supervision one day course, only $6 \%$ of supervisors indicated that they have already attended/attended the doctoral school course. The Doctoral School Supervision course is one of the supports offered by UNL to supervisors. The existence of this course within the Doctoral School shows the importance attributed to supervision by UNL.

\subsection{Doctoral Practices during the PhD from the PhD Students' Lens}

$\mathrm{PhD}$ students choose, from a list of activities, some practices that supervisors usually ask them to do during the doctorate, Table 1.

Sixty-four per cent of the doctorate indicates that the supervisor asks then to have a critical view of their $\mathrm{PhD}$ research. Almost half of the students indicate that the supervisor asks them to participate in meetings of their research group. Forty-five per cent of the doctorate specifies that the supervisor asks them to plan the doctoral research and to do the oral summary/resume of the research when they are in individual meetings. They also ask students to participate as a speaker in national and international congresses or seminars.

Table 1. Percentage of students that identified a specific task (deliver by $\mathrm{PhD}$ supervisor), during the $\mathrm{PhD}$ research time

\begin{tabular}{|c|c|c|}
\hline Domains & My supervisor requests me to... & $\%$ \\
\hline Planning & ... Plan my doctoral research. & 45 \\
\hline \multirow{10}{*}{$\begin{array}{l}\text { Supervision practices during } \\
\text { PhD Research }\end{array}$} & $\ldots$ To take oral stock of the situation of the research I have conducted, in the individual meetings. & 45 \\
\hline & ... Write the thesis throughout the investigation period. & 28 \\
\hline & ... Read articles regularly to discuss in-person meetings. & 28 \\
\hline & ... Make a diary of activities carried out (dated and summarized) or a laboratory notebook. & 23 \\
\hline & ... Write a report regularly on the activities carried out. & 21 \\
\hline & ... Whenever we meet, make a written report of the topics discussed. & 12 \\
\hline & ... Build a portfolio. & 6 \\
\hline & $\ldots$ Write the thesis at the end of the research. & 18 \\
\hline & ... Make an oral presentation at the end of the semester. & 7 \\
\hline & ... Only present the research at the end of it. & 3 \\
\hline \multirow{3}{*}{ Autonomy } & ... Have a critical view of my research. & 64 \\
\hline & ... Try to solve the research problems that arise before asking for his/her help. & 25 \\
\hline & ... Just do what he/she suggests. & 6 \\
\hline \multirow{2}{*}{ Communication } & ... Participate as speaker in national and international congresses or seminars. & 41 \\
\hline & ... Write an article at the end of each year. & 26 \\
\hline \multirow{2}{*}{ Tasks extra doctoral project } & ... Supervise a master's or bachelor's degree, student. & 28 \\
\hline & ... Teach a discipline. & 14 \\
\hline Socialization & ... Participate in meetings of the research group to which I belong. & 48 \\
\hline \multirow{2}{*}{ Evaluation of supervision } & ... Give my opinion of their supervision. & 5 \\
\hline & ... Evaluate his/her supervision. & 1 \\
\hline \multirow{3}{*}{ Supervisor behaviour } & ... Usually, request nothing related to the research project. & 23 \\
\hline & ... I rarely meet my supervisor. & 12 \\
\hline & $\ldots$ To remind him of the theme of my thesis whenever we meet. & 9 \\
\hline
\end{tabular}


It is also interesting to identify the practices that are not proposed by the supervisors majority, during the doctorate research: construct a portfolio; oral presentations at the semester's end of $\mathrm{PhD}$ students; teach a discipline in the higher education institutions where student's is doing the $\mathrm{PhD}$; evaluate the supervisor work; give a student's opinion about supervisors supervision. Six per cent of the supervisor doesn't approve students do tasks that they didn't propose.

It should be underlined that fourteen per cent of the supervisors ask students to teach a discipline (without paying) but the percentage grows to twenty-eight per cent if the task is to supervise bachelor or master students in their research project (also without paying). There is here one paradox, $\mathrm{PhD}$ students' don't have, as their $\mathrm{PhD}$ supervisors (Ribau \& Alves, 2017 and 2018), supervision courses but additionally, they don't have expertise or experience in supervision. And although it can help the students' integration in the research group and their research (if the master project is related to the doctoral research) it takes time and may over-load the student research work.

After the second year, the supervisor invites students to develop a critical view. In the same context, the supervisor appeals to the doctorate (especially during the last year) to try to solve the research problems that arise. Development of communication skills is also an objective, especially in the two last years (which is reinforced by the request for writing papers). Half of the $\mathrm{PhD}$ students report that they are integrated into the research group where they develop the research project, which reflects their integration in the academy.

Nevertheless, it should be highlighted that some doctorate indicates that they rarely meet with their supervisor, a small percentage refers that must remember their theme to a supervisor whenever they meet, and some also mention that the supervisor doesn't demand anything.

From the survey closed questions, it is possible to have more data in order to identify $\mathrm{PhD}$ practices. One hundred and sixty-five $\mathrm{PhD}$ students agreed that they regularly read papers and books since the beginning of the $\mathrm{PhD}$ enrolment.

Regarding the instruments used by $\mathrm{PhD}$ students to monitor their research, it was possible to identify the registration book or laboratory books as the most used. It is interesting to perceive that although only twenty-three per cent of supervisors re-quest students to make a written diary of activities carried out (dated and summarized) or a laboratory notebook, sixty-two per cent of the students indicate that they have writing registration books to monitor their research project.
Concerning the $\mathrm{PhD}$ goals, students view autonomy as one of them. One hundred and seventy-nine PhD students agreed that develop their autonomy is one of their objectives, though only eighty-five students participate, as a collaborator in activities (workshops, seminars, conferences, meetings) in the institution where he/she is doing his research. Two hundred and fifteen students agree that for them, develop research competences is another $\mathrm{PhD}$ aim.

As for the keys to complete the degree, two hundred and twenty-two students (89\%) agreed that acquire new research skills and competencies and knowledge are essential to achieve the degree. One hundred and sixty-six students agree that be creative and innovator is also important to conclude the $\mathrm{PhD}$.

It should be emphasized that $54 \%$ of the $\mathrm{PhD}$ enrolled in full-time indicate that they need more support from the supervisor and $48 \%$ per of students have considered giving up the $\mathrm{PhD}$. It is also important to highlight that $62 \%$ of the $\mathrm{PhD}$ students enrolled in full-time consider that the $\mathrm{PhD}$ journey is solitary. $71 \%$ of the $\mathrm{PhD}$ full-time students that responded to the survey refer that fells that belong to the academy community.

It is interesting to note that only $45 \%$ of part-time $\mathrm{PhD}$ students have already considered giving up, $59 \%$ refer that need more support, and $73 \%$ consider that the $\mathrm{PhD}$ journey is solitary. The feeling of belonging is only perceived by $53 \%$ of part-time students that responded to the survey.

\subsection{The Ideal Supervisor Profile from the PhD Students' Point of View}

To identify the ideal supervisor profile from the doctorate lens, they had to choose the characteristics they most appreciate in a $\mathrm{PhD}$ supervisor, from an inventory, Table 2.

Give feedback timely, be present, accompanied students' research and collaborate with it to solve problems that arise during the $\mathrm{PhD}$ journey are the most appreciated supervisor qualities. The supervisor creativity is an attribute that is only valued by $30 \%$ of the students, but the supervisor is accessible, be present, and accompany the $\mathrm{PhD}$ student is appreciated by $65 \%$ of the students in this study. Nevertheless, only half of the students refer that value clear comments from the supervisor.

The lowest appreciated supervisor characteristics are, be a good listener, be a friend and not interfere with or intervene with the student project decision. These last characteristics (not interfere or intervene) may show the supervisor disinterest in student research completion or the supervisor's confidence in student research decisions. In any case, shows that the student values the supervisor's opinion. 
Table 2. Percentage of $\mathrm{PhD}$ students that chose the sentence to characterize

\begin{tabular}{|l|c|}
\hline Characteristics of a good PhD supervisor... & $\mathbf{\%}$ \\
\hline Give work feedback promptly. & $\mathbf{8 0}$ \\
\hline $\begin{array}{l}\text { Collaborate with the doctorate in solving problems } \\
\text { that arise in the investigation that the student is } \\
\text { carrying out. }\end{array}$ & $\mathbf{7 8}$ \\
\hline $\begin{array}{l}\text { Be honest with the opinions about the doctorate's } \\
\text { work. }\end{array}$ & $\mathbf{7 7}$ \\
\hline Be present. & $\mathbf{6 5}$ \\
\hline Accompany the PhD student in doctoral research. & $\mathbf{6 5}$ \\
\hline Be accessible. & $\mathbf{6 5}$ \\
\hline Be critical & $\mathbf{6 3}$ \\
\hline Be clear in the comments to the doctorate's work. & $\mathbf{5 4}$ \\
\hline Be inspired & 39 \\
\hline $\begin{array}{l}\text { Show that he feels responsible for the failure/success } \\
\text { of the PhD student; }\end{array}$ & 38 \\
\hline Be a patient explainer. & 37 \\
\hline Be active. & 32 \\
\hline Always support the doctoral student. & 31 \\
\hline Be creative. & 30 \\
\hline Be calm. & 27 \\
\hline Be a good listener. & 24 \\
\hline Be a friend. & 17 \\
\hline $\begin{array}{l}\text { Not intervene in the decision making of the doctorate } \\
\text { during the doctorate. }\end{array}$ & 5 \\
\hline Not interfere with research project decision-making- & 3 \\
\hline
\end{tabular}

It is interesting to present some responses to the close questions of the survey and see the difference between the ideal (what students choose as the characteristics of a good supervisor) and the real supervisor (what they find in the field).

Some students reported that to meet with their supervisor, they have to schedule (39\%), and only a little part indicates that they meet regularly with their supervisor (32\%). Only $44 \%$ of the students refer that their supervisor is always available to speak with him/her. Regarding feedback quality, almost thirty per cent agree that their supervisor gives unclear feedback. These results are analogous to the results reported by Baptista in 2014 and 2015. It is possible to perceive that what mature students indicate as difficulties in the supervision process (lack of availability to schedule meetings, the insufficient or lack of prompt and timely feedback, insufficient supervisor support) are also felt by $\mathrm{PhD}$ students at UNL.

\subsection{The PhD Students' Characteristics and Selection Criteria from the Supervisor Lens}

From the data collected, it can be seen that there is a high percentage of agreement on the student's willingness to receive feedback $(91.1 \%)$ and on the student's need to reflect on the development of their project to move forward $(72.3 \%)$. The student "knowing to hear", on the other hand, is not as consensual among supervisors, although the vast majority partially agrees $(44.6 \%)$ or agree $(39.3 \%)$ with the student's need for this characteristic. The ability to know how to listen implies the ability to accept criticism, understand the message, learn from it, and thereby change or maintain a certain attitude, behaviour or line of work.

To understand what information supervisors value when to choose and or accept a $\mathrm{PhD}$ student for supervising, two items (a statement and an open-ended question) were put on the questionnaire. Forty-two per cent of the supervisors $(42.8 \%)$ disagreed with the statement "I only accept mentoring students I already know." Twenty-five supervisors (18.7\%) partially disagreed, 28 supervisors (25\%) partially agreed, and eleven supervisors $(9.8 \%)$ agreed. These results show that student prior knowledge is not a criterion used by most supervisors to select and accept doctoral students.

To better understand how supervisors select and accept PhD students, an open question was posed "When do you accept a PhD student what information/aspects do you consider important?" First, it should be noted that each supervisor has their selection criteria. These depend on his/her view of a doctorate, the supervisor personal goals and extrinsic factors (institution policy, projects in which his/her are involved, professional status). It is found that supervisors select their doctoral students, taking into account several factors, but the most mentioned are the student's personal motivation (23.7\%), evidenced skills and competencies (24.8\%), student personality $(15.8 \%)$, the interest shown by the student $(15.8 \%)$, his / her academic background (12.4\%), his/her professional qualification $(2.8 \%)$, papers published $(1,7 \%)$.

\subsection{Supervisory Practices and Activities Identified by Supervisors}

From the collected data it is possible to verify, that there are tasks that practically all supervisors ask the doctorates to do: read articles (98\%), present results in congresses (94\%), write at least one article during the doctorate (92\%), be a speaker at workshops (88\%), discussing/exchanging ideas not only with the supervisor but also with peers $(86 \%)$, regularly reviewing the status of the tasks performed and identify milestones $(855)$, be proactive monitoring is research $(83 \%)$, and attend meetings of the research group to which they belong $(82 \%)$. Two tasks are required by $50 \%$ or fewer supervisors: doctoral students have written records of their activities $(50 \%)$ and submit an annual report of what they did that year (47\%).

It is important to remember that article writing is not only a form of doctoral pedagogy (Kamler \& Thompson, 2004) but also an activity that facilitates the integration of the doctoral student in the academic field. Dissemination of research also facilitates integration into a scientific career, being one of the quality descriptors of doctoral education and research presented by the League of European 
Research Universities (LERU, 2007).

In a study conducted in 2014 by Pinheiro, Melkers and Youtie, they identified the number of graduate student publications as an indicator of their future school success. These authors report that the number of doctoral students with at least one publication before completing the degree has increased over the last few years. "Co-publication with advisors is found to be an important driving factor in publication activity, along with certain demographic and field characteristics." From this study, the authors emphasize that the publications of graduate students (graduates or masters) and the collaborations they develop during the doctorate are predictors of a later successful and productive career (Pinheiro, Melkers \& Youtie, 2014). In the same vein, a study by Horta e Santos (2016) was carried out regarding the impact of publications during doctorate on the career of doctorates (number of publications, visibility and collaborations) in Portugal. PhD students with a higher number of publications and productivity during the $\mathrm{PhD}$, in the future, will have a higher number of citations and citations during their research career, than doctoral students who did not publish during the doctorate. They also found that who publishes during the doctorate, publishes more articles in which he is the sole author, and engages in peer-reviewed publications from other institutions, suggesting greater levels of international autonomy and dynamics of collaboration (Horta \& Santos, 2016). In this context, the fact that $92 \%$ of supervisors, state that they request the writing of articles is an indication that they are promoting dynamics of integration in the academic environment and the autonomy of doctoral students.

\subsection{The Nature of $P h D$}

The supervisor's perception regard to the nature of the degree, the context in which the doctoral degree takes place, as well as supervisors' perceptions regarding the authorship of the doctoral research project and $\mathrm{PhD}$ thesis, and also the conceptions of what a doctorate is, and the students attribute/ competencies/ learning to achieve it, were studied.

What is the essence of a doctoral degree? What does it presuppose? Is the "know-how to teach" attributes essential for supervising a $\mathrm{PhD}$ student? From the supervisors' answers, it can be seen that only $44.9 \%$ agree that "Knowing how to teach is essential for supervision" and $44.6 \%$ partially agree. It is noteworthy that this perception is reinforced by the answers to "Supervision is the most demanding teaching processes at the university", in which only $23.2 \%$ agree with this statement, and $40.2 \%$ partially agree. In 2013 Bruce and Stoodley presented the results of an investigation they conducted with supervisors about experiencing supervision as teaching at an Australian University. These authors point out that "Supervision as teaching was experienced as promoting supervisor development, imparting academic expertise, upholding academic standards, promoting learning to research. Drawing upon student expertise, enabling student development, venturing into unexplored territory, forming productive communities and contributing to society" (Bruce \& Stoodley, 2013: 226). In the present study, it is clear that supervision is not perceived by all supervisors as a teaching process: only $44.9 \%$ of supervisors agree that knowing how to teach is essential for supervision. On the one hand, because the $\mathrm{PhD}$ teaching process has different characteristics of graduate education and the process of transmission of knowledge is different, on the other, because the background of supervisors (Portuguese and Australian) in terms of Supervisory training is different. In Australia, supervisors have to have supervisory training to do so, in UNL is not necessary to have a Supervisor train.

The knowledge that is built is also not considered the most important in the doctorate for supervisors; only $28.6 \%$ agree with the statement "The most important thing in the doctorate is the knowledge that is built" and $60.7 \%$ partially agree. It should be noted that $56.3 \%$ of supervisors agree with and $34.8 \%$ partially agree with the statement "The creativity and innovation of the supervisor are very important in solving problems that arise during doctoral research."

Within the scope of developing competences, there is a broad consensus regarding the ability to communicate doctoral research, considering $92.9 \%$ of supervisors that doctoral students must have it and there are no supervisors who disagree or partially disagree with it. This result is reinforced by supervisors agreement with "The writing of scientific articles is one of the learnings that should occur during the $\mathrm{PhD}$ ", that reach $81.3 \%$. Also the statement "The development of research skills is the main objective of a $\mathrm{PhD}$ ", reached an agreement of $41.1 \%$, with $50.9 \%$ partially agree with it. "Resilience is one of the characteristics to be developed by the doctoral student during his $\mathrm{PhD}$ " had the agreement of $69.6 \%$ of supervisors, with $15.2 \%$ partially agreeing with it.

To understand the supervisor's perspective regarding the goals of pursuing a $\mathrm{PhD}$, the supervisors were asked the following open question "What is the purpose of a $\mathrm{PhD}$ for you, excluding new knowledge production?" The answers obtained reveal a great diversity of opinions. For $20.8 \%$ are for the doctoral student qualify and $16.8 \%$ are for the student training. The development of autonomy, resilience, resistance and critical spirit needed in research is proposed by $13.9 \%$ supervisors and strengthening research teams are referred by $11.9 \%$. Developing research skills, capacities and tools are indicated for $10.8 \%$ of the supervisor, career progression for $8.9 \%$ of the supervisor and personal enhancement and achievement aimed at $4.9 \%$.

From the supervisor's perspective, the enrolment in a $\mathrm{PhD}$ is related to its professional utility (progression in a career), to intrinsic motives (personal importance), to 
extrinsic motives (professional, economic benefits and public recognition). Also, the nature of the $\mathrm{PhD}$ is implicit in the answers, and the $\mathrm{PhD}$ as a process is identified when supervisors report that the aim of taking the degree is the learning process of doctoral students, the development of competences, capacity and research tools. The perception of the $\mathrm{PhD}$ aim as a preparation or training of the doctoral students, or even a way to strengthening research teams and develop academic staff, reflects the notion of the doctorate as a product (creation of a product- the researcher-with a utility for supervisor - the doctorate will reinforce the supervisor research team).

In a recent survey in Ireland, Loxley and Kerans (2018) asked supervisors about the purpose of pursuing a doctorate. For these authors, the term purpose means that the doctorate is performed in a way that creates or produces a gain or set of gains (benefits) for the doctorate. They could identify four purposes: Instrumentalism, Recognition, Position, and Knowledge Generation. Considering this classification, it is possible to see that in our study a fifth purpose of the $\mathrm{PhD}$ emerges, which is related to the strengthening of the research/development team of academic staff and the training of specialists. It should be noted that if for some supervisors the purpose of pursuing a doctorate was singular and well-defined for others, it had various purposes given its usefulness and significance.

\subsection{Factors that Undermine the Supervision Process}

Since supervision is a human activity, the personal incentive or motivation of the supervisor to perform supervision is a factor that must also be analysed. If the supervisor finds satisfaction and gratification in the activity, he will be more involved in it. The first statement proposed in the questionnaire to understand the intrinsic motivations or what leads, supervisors to supervise was related to the idea that the supervisor does not have enough time to perform supervision (excessive workload) - "I have a lot of work and little time to do doctoral supervision"-. The results allow us to conclude that this population of supervisors does not feel that they have little time to perform supervision (34.8\% disagree with the statement) and only $9.8 \%$ agree with it.

Regarding the burden that supervision causes on the work of a researcher/teacher, there is no consensus, with $25.0 \%$ of the supervisors agreeing and $29.5 \%$ disagreeing, with it. Regarding the importance of the $\mathrm{PhD}$ project conclusion for the supervisor, there is a unanimity: $91.1 \%$ agree with the statement "It is important to me, that my $\mathrm{PhD}$ student complete the doctorate", which shows that supervisors are motivated to supervise. Corroborating this conclusion, $80.4 \%$ of supervisors agree with the statement "I feel fulfilled as a teacher when I advise PhD students".

To better understand what leads a supervisor to supervise doctoral students, the following question was asked: "What reasons lead a supervisor to mentor doctoral students?" This question also made it possible to understand the general conceptions of the doctorate, namely as to the nature of the doctorate (process, product and context) and its value (usefulness and importance). From the answers given by supervisors, it was possible to notice that the reasons that lead a supervisor to perform doctoral supervision are the research aid held by doctoral students $(19.1 \%)$, knowledge production $(14.5 \%)$, the supervisors' professional need for career progression $(12.8 \%)$, the students' motivation and interest in the research topic $(10.9 \%)$ and the professional duty of the supervisor $(10.0 \%)$. With less than $10 \%$ mentions are the knowledge transmission $(9.1 \%)$, the creation of research teams $(4.5 \%)$, the teaching $(4.5 \%)$, the development of research that supervision provides $(3.6 \%)$, personal accomplishment (4.5\%) and paper publication (2.7\%).

Of note is a supervisor's response when he states that "Much of the investigators' experimental work is performed by PhD and postdoctoral students. This is the only way to achieve international productivity rates. Co-supervised students ensure collaborative research." This comment and the percentage of supervisors who report that they supervise for obtaining research help $(19.1 \%)$ is supported by the comment from doctoral students (elsewhere). This reality is also referred to in the study by Johnston, Sampson, Comer and Brog (2016) when referring that "Doctors candidates contribute significantly to the academic life and reputation of universities. (...) Approximately two-thirds of the research outputs in Australia have been attributed to research students (Pearson, Evans \& Macauley, 2006). This perspective must be taken into account by the institution, as UNL intends to maintain high-quality standards in research and thus to feature in international rankings in prominent places.

From this analysis also emerges a new paradigm, which is related to the criteria of how a student is selected by the supervisor. Some supervisors choose the $\mathrm{PhD}$ student taking into account the subjects of the student's project and how the student intends to develop it. This is a change to the current paradigm (students choose supervisors concerning the research themes supervisor to propose).

It is interesting to note that some of the reasons given by supervisors for performing doctoral supervision are related to the supervisor's career (paper publication, career progression, professional duty), but some reasons reflect the pleasure to develop science. These differences underlie the various perceptions and meanings of what is (Nature of the degree) and what is the purpose (usefulness and instrumentality) of the doctorate, for these supervisors. Moreover, the reasons given will result in different supervisors' involvement in the supervisory process and imply different student practices and experiences.

\section{Conclusions}

This paper aims to bring some light to the $\mathrm{PhD}$ practices 
in UNL, from the students' lens and the supervisor point of view. The PhD students in these research work are mature, but also a novice (Lee, 2008; Lee, Brennan \& Green, 2009). Not only the novice students report that they sometimes fill lost and need more support but also mature students. From these data it is possible to perceive that only half of the $\mathrm{PhD}$ students, that respond to the survey, are asked to participate in the research group meetings (the majority of these students are in the third and in the four years of the doctorate), plane there research and participate as speaker in national or international congress. A minority of students (twenty-eight per cent) are also UNL supervisors of master or bachelor students. This situation may overload the $\mathrm{PhD}$ student during the doctorate causing attrition, and it should be rethought by supervisors (Ribau \& Mariana, 2017 e 2018). The supervisor's work (supervision) isn't evaluated by $\mathrm{PhD}$ students.

The most requested action from the supervisors is to students develop critical thinking regarding their $\mathrm{PhD}$ project. Nevertheless, only twenty-five per cent of them, request students to make an effort to solve the research problems that arise, before asking for his/her help. These two issues are related to autonomy development.

It is possible to recognize from our data that, students appreciated the supervisor that is available to accompany the student research. The ideal supervisor must be available, present and be honest, accessible and also critical. One important quality for the ideal supervisor is the collaboration with the students. Another characteristic is, give clear, quick and timely feedback. In a study implemented in Aveiro University, a Portuguese university, the author (Baptista, 2015) analysed the doctoral mature student's voice and found out the ideal and the real doctoral supervisor "role and practice". The results obtained by Baptista in a focus group with mature students are similar to the results that we obtained in the present research. Although the mature students in that research also refer that the ideal supervisor must have emotional intelligence, be empathic, and possess social skills, and in-depth scientific knowledge in the area (Batista, 2014 e 2015).

Lack of supervisor support referred by some students, the loneliness reported by the $\mathrm{PhD}$ students, the lack of timely and suitable feedback stated by some students are issues that must be improved in UNL. So the UNL structures that organize and regulate or that are related to the third-cycle should have in mind these results to promote more successful supervision that can satisfy both student and supervisor. But it should be referred and underlined that the attrition rate in UNL has decreased in the last years (Ribau \& Alves, 2017) and that it is a result of a major effort that some of the structures related to the third cycle are doing (as an example, almost sixty-two per cent of the $\mathrm{PhD}$ students, that respond to the survey, have already been enrolled in Doctoral School short courses).

From the supervisors' answers, it is possible to clarify some guidelines that allow us to understand, not only how the selection is done, but also how it can be improved. It also provides information to future doctoral candidates that pretended to enrol in a $\mathrm{PhD}$ at UNL. It is important to highlight that from these data also emerges the concept of doctoral learning, predominantly in the supervisors who participated in this study, as transformative learning that is based on critical thinking and critical reflection on practice and about practice. This ability to reflect on action allows for a continuous learning process (Schön, 2013), favoured by two tasks requested by the supervisors: that students have a critical view of their research; present an oral summary of their research activities (state of "art") requested at individual meetings. This last task performed by the doctoral students involves the construction of a framework, a reflection on the objectives it set itself, the planning it did, how it managed and executed the planning and what it achieved. Another emerging concept in the present research is related to learning through formal or informal conversations that take place between supervisor and doctoral student. Cunliffe in 2002 and De Haan in 2011 analyse the development of a dialogue of critical reflection within a learning relationship, from learning management and the relationship of coaching. In this sense, Fillery-Travis and Robinson (2018) refer "Cunliffe (2002) takes a social construction that assumes that it is through our interactions with the other that we construct our social realities. She reframes management learning as a reflective dialogic practice where managers make sense of their world and practice. (...) Not all conversations are learning conversation- the art of such practice is the reworking of tacit knowing (knowing from within) with the explicit knowledge (e.g. theoretical forms) to make sense of experience or to move us from when we are "stuck" and unable to make sense of a situation or concept "(Fillery-Travis \& Robinson, 2018: 847). In this sense, the dialogue between the supervisor and the doctoral student is more than an exchange of ideas, but rather a means of creating new knowledge (Antonacopolou, 2009; Bohm, 2013).

\section{REFERENCES}

[1] Abiddin, N. \& West, M. (2007). Responsibilities of graduate student: The review of research student policies. Journal of Social Sciences, 3, 7-17.

[2] Ali, A., \& Kohun, F. (2007). Dealing with social isolation to minimize doctoral attrition: A four stage framework. International Journal of doctoral Studies, 2, 33-49.

[3] Aitchison, C. \& Guerin, C. (2014). Writing groups for doctoral education and beyond: innovations in theory and practice. Routledge: London \& New York.

[4] Antonacopoulou, E. (2009). Impact and scholarship: Unlearning and practicising to co-create actionable knowledge. Management Learning, 40, 421-430. 
[5] Ayers, N., Kiley, M., Jones, N., McDermott, M-L \& Hawkins, M. (2016). Using learning plans to support doctoral candidates. Innovations in Education and Teaching International, DOI: 10.1080/14703297.2016.1233074

[6] Baptista, A. (2014). With all my heart: Mature students' emotions while doing a research-based $\mathrm{PhD}$. Procedia Social and Behavioral Sciences, 114, 914-918.

[7] Baptista, A. (2015). Mature students' voices on the ideal and the reality of doctoral supervisors' role and practice. Procedia - Social and Behavioral Sciences, 191, 1544-1551.

[8] Bartlett, A., \& Mercer, G. (2001). Mostly Metaphors: Theorizing from a Practice of Supervision. In: A. Barlett, \& G. Mercer (Eds.), Postgraduate Research Supervision: Transforming (R) elations (pp. 55-69). New York: Peter Lang.

[9] Beck, M. (2016). Examining doctoral attrition: a self-determination theory approach. The Nebraska Educator: A student-Led Journal, 33, 5-19.

[10] Bohm, D. (2013). On dialogue. London: Routledge.

[11] Bruce, C \& Stoodley, I. (2013). Experiencing higher degree research supervision as teaching. Studies in Higher education, 38(2) 226-241.

[12] Burnett, P. (1999). The supervision of doctoral dissertations using a collaborative cohort model. Counselor Education and Supervision, 39, 46-52.

[13] Carter, S., Kensigton-Miller, B. \& Courtney, M. (2017). Doctoral supervision practice: what's the problem and how can we help academics. Journal of perspectives in applied academic practice, 5(1), 13-22.

[14] Connell, R. (1985). How to supervise a PhD. Vestes, 2 (1985), pp. 38-41.

[15] Corcelles, M., Cano, M., Liesa, E., González-Ocampo, G. \& Castelló, M. (2019). Positive and negative experiences related to doctoral studies conditions. Higher Education Research \& Development. DOI: 10.1080/07294360.2019.1602596.

[16] Cunliffe, A. (2002). Reflexive dialogical practice in Management learning. Management Learning, 33, 36-61.

[17] De Haan, E. (2011). Relational coaching: journeys towards mastering one-to-one learning. Hoboken, NJ, John Wiley.

[18] Denis, C., Colet, N. \& Lison, C. (2019). Doctoral Supervision in North America: perception and Challenges of Supervisor and Supervisee. Higher Education Studies, 9, 30-39.

[19] Delamont, S., Atkinson, P. \& Parry, O. (1997). Supervising $\mathrm{PhD}$. A guide to success. London: The Society for Research into Higher Education \& Open University Press.

[20] Dorn, S., Papalewis, R. \& Brown, R. (1995). Educators earning their doctorates: doctoral students' perceptions regarding cohesiveness and persistence. Education, 116, 305-14.

[21] Engels-Schwarzpaul, A.- C. (2013). Non-Traditional Ways to the Doctorate. In A.-C. Engels-Schwarzpaul, \& M.A. Peters (Eds.), Of other Thoughts: Non-Traditional Ways to the Doctorate: A Guidebook for Candidates and
Supervisors (1-14). Rotterdam/Boston/Taipei: Sense Publishers.

[22] Fenge, L. (2012). Enhancing the doctoral journey: the role of group supervision in supporting collaborative learning and creativity. Studies in Higher Education, 37, 401-414.

[23] Fraser, R. \& Mathews, A. (1999). An evaluation of the desirable characteristics of a supervisor. Australian Universities' Review, 42, 5-7.

[24] Fillery-Travis, A. \& Robinson, L. (2018). Making the familiar strange- a research pedagogy for practice. Studies in Higher Education, 43 (5), 841-853.

[25] Gardner, S. (2008). Fitting the model of graduated school: a quantitative study of socialization in doctorate education. Innovations in Higher Education, 33, 125-138.

[26] Gradner, S. (2010). Contrasting the socialization experiences of doctoral students in high- and low completing departments: a qualitative analysis of disciplinary contexts at one institution. The Journal of Higher Education, 81, 61-81.

[27] Grant, B. (1999). Walking on a rackety bridge: mapping supervision. Retrieved November 2016, fromhttp://www.h erdsa.org.au/wp-content/uploads/conference/1999/pdf/gran t.pdf.

[28] Green, B. (2005). Unfinished business: Subjectivity and supervision. Higher Education Research \& Development, 24(2), 151-163.

[29] Greenbaum, T. L. (2000). Moderating Focus Groups: A Practical Guide for Group Facilitation. SAGE, Thousand Oaks.

[30] Karmler, B \& Thompson, P. (2004). Driven to abstraction: doctoral supervsision and writing pedagogies. Teaching in Higher Education, 9, 195-209.

[31] Kehm, B.M. (2006). Doctoral education in Europe and North America: a comparative analysis. Retrieved October 2015, from

http://www.portlandpress.com/pp/books/online/fyos/083/0 067/0830067.pdf.

[32] Kiley, M. (2011). Developments in research supervisor training: causes and responses. Studies in Higher Education, 36(5) 585-599.

[33] Kobayashi, S., Grout, B. \& Rump, C. (2015). Opportunities to learn scientific thinking in joint doctoral supervision. Innovations in Education and teaching International, 52, 41-51.

[34] Halse, C \& Malfroy, J. (2010). Retheorizing doctoral supervision as professional work. Studies in Higher Education, 35, 79-92.

[35] Holdaway, E. (1996). Current issues in graduate education. Journal of higher Education Policy and Management, 18, $59-74$

[36] Horta, H \& Santos, J. (2016). The Impact of Publishing during PhD Studies on Career Research Publication, Visibility, and Collaborations. Res High Educ, 57, 28-50. DOI 10.1007/s11162-015-9380-0

[37] Johnston, L., Sampson, K. A., Comer, K. \& Brogt, E. (2016). 
Using doctoral experience survey data to support developments in postgraduate supervision and support. International Journal of Doctoral Studies, 11, 185-203.

[38] Latona, K. \& Browne, M. (2001). Factors associated with completion of research higher degrees. Higher Education Series. Canberra: Higher Education Division, Department of Education, Training and Youth Affairs.

[39] Lee, A. (2018). How can we develop supervisors for the modern doctorate? Studies in higher Education, 43, 878-890.

[40] Lee A. \& Green, B. (2009). Supervision as metaphor. Studies in Higher Education, 34 (6), 615-630.

[41] Lindsay, S. (2015). What works for doctoral students in completing their thesis? Teaching in Higher Education, 20, 183-196.

[42] Love, A. \& Street, A. (1998). Supervision as collaborative problem-solving: An integrative approach to postgraduate research education. In M Kiley, \& G. Mullins (Eds.), Quality in Postgraduate Research: Managing the New Agenda. Proceeding of the 1998 Quality in Postgraduate Research Conference (pp.139-159). Adelaide, Australia: The Advisory Centre for University Education, University of Adelaide.

[43] Loxley, A. \& Kearns, M. (2018). Finding a purpose for the doctorate? A view from the supervisors. Studies in Higher Education, 43 (5), 826-840.

[44] Malfroy, J. (2005). Doctoral supervision, workplace research and changing pedagogical practice. Higher Education Research \& Development, 24 (2), 165-178.

[45] Mason. A \& Hickman, J. (2017). Students supporting students on the $\mathrm{PhD}$ journey: An evaluation of a mentoring scheme for international doctoral students. Innovations in Education and Teaching International, https://doi.org/10.1080/14703297.2017.1392889

[46] Maxwell, T. \& Smyth, R. (2010). Research supervision: The research management matrix. Higher Education, 59, 407-422.

[47] Maxwell, T. \& Smyth, R. (2011). Higher degree research supervision: From practice toward theory. Higher Education Research \& Development, 30 (2), 219-231.

[48] ORPHEUS (2011 e 2012) homepage (www.orpheus-med.or g).

[49] Pearson, M. (1996). Professionalizing PhD education to enhance the quality of student experience. Higher Education, 22, 303-320.

[50] Pearson, M. (2012). Building bridges: higher degree student retention and counseling's support. Journal of Higher Education Policy and Management, 34, 187-199.

[51] Pearson, M., Evans, T. \& Macauley, P. (2012) Exploring the nexus between research and doctoral education. AARE APERA International conference, Sydney, 1-9.

[52] Pinheiro D., Melkers J. \& Youtie, J. (2014). Learning to play the game: Student publishing as an indicator of future scholarly success. Technological Forecasting \& Social Change, 81, 56-66.
[53] Repečkaitè, D. (2016). Reframing European doctoral training for the new ERA. European Journal of Higher Education, 6, 256-270.

[54] Ribau, I. \& Alves, M. (2017). Doctoral supervision at Nova Lisbon University: an exploratory study. European Proceedings of Social and Behavioural Sciences. Paper presented at 8th ICEEPSY, 11- 14 October Porto, Portugal.

[55] Ribau, I. \& Alves, M. (2018). Doctoral supervision at NOVA Lisbon University: an overview. Universal Journal of Educational Research, 6, 2530 - 2542 DOI: 10.13189/uj er.2018.061118

[56] Vekkaila, J. Pyhältö, K., Hakkarainen, K., Keskinen,J \& Lonka, K. (2012). Doctoral students' key learning experiences in the natural sciences. International Journal for Researcher Development, 3, 154-183.

[57] Wakler, G.E., Golde, C.M., Jones, L., Bueschel, A.C., \& Hutchings, P. (2008). The Formation of Scholars: Rethinking Doctoral Education for the Twenty-First Century. San Francisco: Jossey-Bass \& The Carnegie Foundation for the Advancement of Teaching.

[58] Wegener, C. \& Tanggaard, L. (2013). Supervisor and student Co-writing: an apprenticeship perspective. Forum Qualitative Social Research, 14 (3), Art.14.

[59] Wollast, R., Boudrenghien,G., Lindem, N., Galand, B., Roland, N., Devos, C., De Clercq, M., Klein, O., Azzi, A. \& Frenay, M. (2018). Who area the doctoral students who drop out? Factors associated with the rate of doctoral degree completion in Universities. International Journal of Higher Education, 7, 143-156. 